\title{
Accounting Information System and Its Role on Business Performance: A Theoretical Study
}

\author{
Ahamed Al-dmour ${ }^{1}$, Khaled Mofawiz Al-Fawaz ${ }^{2}$, Rand Al-dmour ${ }^{3} \&$ Nurah Musa Allozi ${ }^{4}$ \\ ${ }^{1}$ Electronic and Computer Engineering Department, Engineering School, Brunel University, London, UK \\ 2 Management Information System Department, Faculty of Economic and Administration, King AbdulAziz \\ University, Jeddah, Kingdom of Saudi Arabia \\ ${ }^{3}$ Management Information Systems Department, School of Business, The University of Jordan, Amman, Jordan \\ ${ }^{4}$ Department of Accounting, School of Business, The University of Jordan, Amman, Jordan \\ Correspondence: Ahamed Al-dmour, Electronic and Computer Engineering Department, Engineering School, Brunel \\ University, London, UK. Tel: 962-6-5355-000. E-mail: eepgaaag@brunel.ac.uk
}

Received: July 30, 2017

doi:10.5430/jms.v8n4p79
Accepted: August 9, 2017

Online Published: August 29, 2017

URL: https://doi.org/10.5430/jms.v8n4p79

\begin{abstract}
While some researchers did not find a direct relationship between Accounting Information System and a firm's business performance, others did. In this regard, it has been confirmed that implementing a proper Accounting Information System is an enabler to competitive advantage. Indeed, causal links were founded between Accounting Information System and firm performance. This study aims to review the literature that relates to such links. The conclusions of the current study are provided and areas for further research are also addressed.
\end{abstract}

Keywords: accounting information system, business performance

\section{Introduction}

Some researchers (i.e. Masa'deh, Tayeh, Al-Jarrah \& Tarhini, 2015) argued that since the Accounting Information System (AIS) has been an important concern to the business community (Abbasi et al., 2015; Masa'deh, 2013; Shannak et al., 2012), as it is not only helps firms recognize the potential benefits from investments in IT (Alkalha et al., 2012; Altamony et al, 2012), but also improves business performance (Abu-Shanab et al, 2015). However, it is known that no single measure of performance could fully account for all aspects of firm performance (Ibrahim et al., 2010; Masa'deh \& Shannak, 2012; Obeidat et al., 2013). Moreover, although firm performance has been assessed using a diversity of measures, there is no universal guideline regarding the appropriate choice. Researchers measure performance objectively and/or subjectively, where objective measurements depend upon profit and financial data, and subjective measurements rely on managerial assessments. On the other hand, some researchers used both methods to ascertain firm performance, which enhances the reliability of their conclusions. Initially, the Financial Reporting Standards (FRS's) and Statements of Standard Practices (SSAP's) dealt with the accounting standards, and offered guidelines that covered a considerable variety of accounting issues. For instance, public companies are required to disclose in their financial statements several figures such as the chairman's statement; directors' report; profit and loss account; balance sheet; cash flow statement; notes to the accounts; and auditors' report. In addition, analysts use a well-known technique in analyzing the figures taken from company financial statement, ratio analysis. The main purposes of the analysis of ratios can be summarized as ascertaining the performance of the company, determining its financial strength, and using them for comparative purposes. Consequently, by applying ratio analysis, researchers use profitability (accounting) ratios and/or financial (market) ratios.

\section{Literature Review}

Because Sys Trust was created after WebTrust, there is a lack of empirical research available in that perspective. In their study of electronic data interchange (EDI), Khazanchi \& Sutton (2001) give evidence of the requirement for systems assurance, illustrating that numerous companies enforcing these systems do not use them to full benefit. This shows that entities authorizing EDI for their clients or customers should require assurance of suitable functioning. Results of these studies recommend a demand for trust services. Consequently, it follows that there should be a positive effect on the business of clients that meet approved trust services standards. Moreover, a study from Havelka 
et al. (1998) argues that expression of agreement on measurement criteria for assurance services among providers and users will enable a more effective and efficient production of those services.

Sys Trust is one of the models to update Internal Control Systems (ICS) of AIS through frame working the technological variables which affect designing AIS. Due to such nature, much of the practical studies have been implemented using the principles and criteria of Sys Trust to examine quality and performance of AIS. The term ICS has been used by COSO (1992) to refer to the risks associated with ineffectiveness management of public companies, both large and small. Integrated framework of COSO has long served as a blueprint for establishing internal controls that promote efficiency, minimize risks, help check the reliability of financial statements, and comply with laws and regulations. According to COSO's study, ICS is no longer accounting concept. COSO's report has outlined 26 fundamental principles associated with the five key components of ICS: (i) control environment, (ii) risk assessment, (iii) control activities, (iv) information and communication, and (v) monitoring. ISACF (2001) considers the control objectives associated with use of IT. The study is widely known as COBIT. COBIT consists of three control groups: business objectives, IT resources, and IT-based process. The key feature of COBIT is coming from the fact that it has developed 36 standards of control related to security of IT-based AIS. The impact of IT formed an accounting process on the operational variables of cost and productivity, and profitability has been addressed by Casolaro \& Gobbi (2004). The study was conducted on more than 600 banks belonging to the Italian banking industry. The study concludes with the facts that intensive use of IT-based AIS has reasonable impact on: (i) reduction of banking services cost, (ii) expansion of banking services package, and (iii) increasing banking profit. Another study was conducted by Raupeliene \& Stabingis (2003) has considered the effectiveness of IT based AIS. The study has developed a quantitative model based on set of technological, economics, and social parameters.

Boritz (2005) conducts an extensive review of the literature to identify the key attributes of information integrity and related issues. He brought two focus groups of experienced practitioners to discuss the documented findings extracted from the literature review through questionnaire examining the core concepts of information integrity and it elements. Boritz (2005) considers information security as one of the core attributes for information integrity. This security should cover the following areas: Physical access controls and Logical access controls. The results indicate that the security has a lower impairment severity score than other severe practical aspects, such as availability and verifiability. Boritz's such findings refer to the effective use of security controls in the organizations represented. In his study, Coe (2005) focuses on the fulfillment of Sarbanes-Oxley act 2002 that requires public companies to report about the effectiveness of their internal control systems Coe. In this study, it is explained that the American companies are using COBIT for Sarbanes-Oxley act 2002 compliance, and this is because its objectives have been mapped to COSO in a publication entitled IT Control Objectives for Sarbanes-Oxley. COBIT also has been mapped to popular enterprise resource planning (ERP) systems, like SAP, Oracle and PeopleSoft.

This mapping and related guidance provides COBIT with framework references and methodologies for auditing and testing the major ERP systems. But it is decided later to use Sys Trust service to ensure the company's systems carry-out business processes reliably. Herein, Coe establishes five-step processes showing how the CPAs can use the trust service framework to evaluate a company's IT controls when the entity primarily uses the COSO approach. These steps are: (i) Use COSO framework to identify the risks in each business cycle and the controls that mitigate them, (ii). Gather initial IT information, (iii) Identify all information systems that relate to financial reporting. (iv) Be used to trust services framework to create one overall IT matrix, (v) Assess the controls identified in the matrixes created above. Martin (2005) mentions the same steps in his study, in which he tries to explain how information system auditor can use the AICPA/CICA trust services framework to evaluate internal controls, particularly controls over information technology. The participants in the experiment were 481 middle and upper-level managers from a wide range of functional areas. The study concludes that auditor-provided assurances on information systems availability security, integrity and maintainability will show significant key effects with respect to the probability of the participant entering into a contractual agreement with the ASP organization. In addition, the comfort level of the participant with the reliability of the ASP organization's ERP system will increase. In the same perspective, Mauldin et al. (2006) investigate the possible demand for third-party assurance reports in business-to-business electronic commerce (B2B e-commerce) by observing the purchase decisions of 95 professionals' to advise using a B2B exchange. The experiment uses the $2 \times 2$ between subjects design, and varies the assurance scope (system related assurance vs. data related assurance) and assurance timing (continuous assurance vs. static assurance) with another control condition of no assurance. The results of the study show that there is more probability of purchasing professionals advising using the exchange when general assurance over the reliability of the exchange's system exists, than when specific assurance over the reliability of transaction information exists. There is also a greater chance of 
purchasing professionals advising using the exchange when the assurance report is continuous than when it is static, issued at a given time.

However, the results also suggest that those participating are less probable to recommend using the exchange when specific information assurance or static assurance exists than when assurance does not exist at all. Also, Meharia (2011) aims to study the effects of assurance services and the trust in the mobile payment system on how users' use the system. To demonstrate this matter, the study depends on the Technology Acceptance Model (TAM). The study finds that the users' intention to use their attitude towards the system determines their real use. Their attitude towards the system is decided by the apparent usefulness of the system and the simplicity of use. However, the study adds that the assurance on the security, availability, confidentiality, privacy, and process integrity of the system will have a positive influence on the users' attitude towards the system, in combination with the apparent usefulness and simplicity of use. Also, from a security perspective, Siponen \& Oinas-Kukkonen (2007) reconcile prior security research literature and emphasize the distinct importance of accessibility and availability as it relates to communication issues, like user authentication and appropriate maintenance of data retention. Strong et al. (1997) also segregate and highlight the importance of accessibility as a determinant of data quality. In particular, they emphasize the importance of access security and timely availability to data. Likewise, Nelson et al. (2005) argue that accessibility represents a system attribute that is distinct but similar in importance to the system's ability to produce reliable data, although they argue that this impact of accessibility is second in order of influence to the system's processing reliability. Consequently, it is apparent that system assurance has a positive influence on system users, their reliance and, therefore, on their decisions, particularly when this assurance is provided constantly, which is more suitable according to the present changing environment. In reviewing the literature, it can be seen that Certified Public Accountants (CPAs) can provide assurance on RTA Information Systems. CPAs are accepted as independent parties that provide assurance concerning the accuracy and fairness of financial information. Also, CPAs are well-informed about the subject matter to be assured and the assurance matters, recognized for their independence, objectivity and reliability (Boritz \& Hunton, 2002), and acquire advanced technical competencies (Burton, et al., 2012).

Boritz \& Hunton (2002) aim to assess the extent to which auditor-provided systems reliability assurance affects potential service recipients' (i) likelihood of recommending that their company should enter into a contractual agreement with the service provider, and (ii) comfort level with the reliability of the service provider's information systems. Based on an experiment on 481 middle- and upper-level managers from a broad spectrum of functional areas participating in the study, the conclusion is that auditor-provided assurances on information systems availability security, integrity and maintainability will exhibit significant main effects with respect to the participants' likelihood of entering into a contractual agreement with the ASP firm and the participants' comfort level with the reliability of the ASP firm's ERP system will increase. Similarly, Greenberg et al. (2012) attempt to investigate the impact of Sys Trust criteria (availability, integrity and security) on users' intention to use online accounting systems and their reliability. Based on the TAM, the study posits that the intention to adopt online systems depend on the perceived usefulness of the system, perceived ease of use, trust in system reliability, and trust in the internet. The study finds that users' intention to adopt the online accounting system is higher when users' trust in system reliability and trust in the internet are higher. The results of the study suggest that the reliability of a system, as measured by Sys Trust criteria, is relevant to the decisions related to the intention to adopt online accounting systems. Furthermore, it is predicted that accounting organizations will benefit from their long experience of financial audits and will probably surpass other types of assurance providers in the formal application of non-financial assurance services (Perego, 2009). Additionally, when providing financial matters, CPAs should follow strict and comprehensive ethical and professional standards (Boritz \& Hunton, 2002). For this reason, the American Institute of Certified Public Accountants (AICPA) considers assurance service on electronic systems a logical and natural extension to the already present services that the auditor provides (www.aicpa.org, 2007).

Experimental work indicates that there would be demand for both WebTrust (Hunton et al., 2000; Lala et al., 2002) and Sys Trust (Boritz \& Hunton, 2002) in the marketplace. Yet, as Bedard et al. (2005) note, there are a lot of issues, questions and risks in Sys Trust engagements, and most auditors are leery about delving into the ill-defined arena of systems reliability assurance. Only limited research to date has looked at ways in which to improve and deliver systems reliability assurance. Havelka et al. (1998) conduct a series of focus groups with systems development teams in order to establish criteria for assessing the quality of the information. Arnold et al. (2000) explore the market demand for graded reporting of systems quality versus use of a traditional auditor's binary reporting model. These studies represent the first incremental steps in understanding systems reliability assurance. The domain is wide, open, and in great need of additional research. While Sys Trust provides some broad criteria that must be considered in 
assessing systems reliability, little is known about how to go about assessing these criteria effectively. Given the major role that IT systems play, particularly in enterprise systems environments, the profession must rapidly advance its ability to assess systems quality and academic researchers need to step forward in helping answer the difficult questions that to date present barriers to widespread systems reliability assurance efforts.

After reviewing the previous studies, in this specific area of research, relating to reliability of CAIS control systems, it can be observed that there are not enough studies available, and this could be due to the fact that this area of research is reasonably new. In addition, many of the studies in this subject are administered on a small level and connected with combined studies from the fields of business management, computer science, and at times engineering. They are often in the form of reports or descriptive studies, and rarely experimental. To summarize, there is a lack of academic literature on the issues of trust services and its influence on the quality of financial. It should also be noted that some of the investigations are conducted in isolation, without benefit from the experience of findings from other studies.

\subsection{The Business Performance Concepts}

According to the researchers, Miller (1992), Bledsoe (1997), Abernethy \& Lilis (1995), and Choe (2002); non-financial performance provides various strategic advantages, such as quality improvement and cutting down the delivery time. Non-financial performance was used by Tuanmat \& Smith (2011) to measure organizational outcome, as with respect to product availability, product quality, and sales service and support. Sousa, et al. (2006) also used productivity, customer satisfaction, and customer needs to assess the company's performance. Furthermore, Isobe, et al. (2008) developed a list of long-term performance indicators, including new product and technological innovations. In addition, there is a growing literature on the use of non-financial measures in the West. For example, in the UK, Bhimani (1994) and Dugdale (1994) wrote that companies were quite open to the use of non-financial measures. According to Pierce \& O'Dea (1998), over 50\% of respondents in Ireland ranked the use of non-financial measures as very frequent or often. Furthermore, Ittner \& Larcker (2003, p.95) looked into implementation issues for non-financial performance measures, and concluded by saying that "they have become a shabby substitute for financial performance" and "they will offer little guidance unless the process for choosing and analyzing them comes to rely less on generic performance measurement frameworks and managerial guesswork and more on sophisticated quantitative and qualitative inquiries into the factors actually contributing to economic results".

The shortfalls of outdated financial performance measures have steered organizations towards embracing non-financial performance measures, nonetheless these measures also have shortcomings. These relate to the range of non-financial performance measures, and the problem arising from choosing suitable measures, given that there is no ideal mix of performance measures. Moreover, measuring organizations' financial performance is intrinsically straightforward, because there are rules and guidelines that define the financial measures. On the other hand, non-financial performance measures cannot be subject to the same rules or guidelines. Still, the establishment of non-financial performance measures should be related to the target settings, and rewards and incentives also need to be reflected (Otley, 2001). Arguments in support of such subjective measures also include difficulties with collecting qualitative performance data from firms and with the reliability of such data arising from divergent accounting methods used by firms.

At the same time, using financial performance as a measure of the success or failure of IS has various advantages (Antonio Pérez-Méndez \& Ángel Machado-Cabezas, 2015). Among these, the fact that performance measurement is vital to the success of the company because it creates understanding, forms behavior, and improves competitiveness (Gunasegaran, Williams \& McGaughey, 2005). Furthermore, financial performance reflects a common objective of all the company's IS and/or management processes, which makes it simpler to access their service. Lastly, despite their limitations, financial data has the advantage of being accurate and objective (Parker, 2000), while intermediary, non-financial aims are often subjective, since they rely on personal opinions. Therefore, the assessment of non-financial aims may rely on the job held by the respondent (Anderson \& Young, 1999). Branch (2000) maintains that financial indicators based on accounting information are adequate enough to determine the value for shareholders. A manufacturing firm financial performance is directly impacted by its position in the market. Profitability can be decomposed into its two key components, namely its net turnover and its net profit margin. Ross et al. (1996) argues that both can influence the profitability of a company one time. If a high turnover indicates the improved use of the assets its and therefore higher efficiency, a higher profit margin means that the entity has marked market power. Menon \& Williams (1994) found out that, objective performance measures comprise indicators such as profit growth, revenue growth, as well as return on the capital employed. 


\section{Conclusions}

Financial consultants Stern Stewart \& Co. created Market Value Added (MVA), a measure of the excess value a company has given to its shareholders over the total amount of their investments. This ranking is based on eight more traditional aspects of financial performance such as, total return for one and three years, sales growth for one and three years, profit growth for one and three years, net margin, besides a return on equity. Further, Verschoor (1999) draws attention to other financial measures such as value of long-term investment, financial soundness, and use of corporate assets. Ejoh \& Ejom (2014) mention accounting-based performance using three indicators: return on assets (ROA), return on equity (ROE), and return on sales (ROS). Each measure was calculated by dividing net income by total assets, total common equity, and total net sales. However, several authors (e.g., Kaplan \& Norton, 1992; Ibrahim, 1999) indicated that although financial measures are important, they are not sufficient for a good performance evaluation system. The system should further include non-financial measures of performance. Kelly (2007) justifies this by indicating that firm value is developed through various activities that promote critical success factors. These factors include innovation, quality, productivity, and customer satisfaction. Also, Gu (2005) mentioned that such success factors improve future financial performance, in due course. Current summary financial measures that report financial results, such as operating income and return on investment, are not likely to fully reveal the long-term consequences of these activities. So, numerous firms supplement summary financial measures with nonfinancial measures that demonstrate principal value-creating activities (Kaplan \& Norton, 2001a, b, c).

In addition, scholars (e.g. Al Azmi et al., 2012; Alshurideh, et al., 2012; Masa'deh, 2012; Obeidat, et al., 2012; Kannan \& Gharibeh, 2013; Hajir, et al., 2015; Masa'deh, et al. 2013, 2014, 2015, 2017; Vratskikh et al., 2016; Obeidat et al., 2017; Tarhini et al., 2017) emphasize the need for large firms to integrate their IT systems with their Knowledge Management (KM) strategies and processes in order to survive in their highly competitive business environments, which in turn could accelerate the managerial decisions as well. Consequently, further research is required to examine the role of AIS on financial and nonfinancial performance.

\section{References}

Abbasi, M.S., Tarhini, A., Elyas, T., \& Shah, F. (2015). Impact of individualism and collectivism over the individual's technology acceptance behaviour: A multi-group analysis between Pakistan and Turkey. Journal of Enterprise Information Management, 28(6), 747-768. https://doi.org/10.1108/JEIM-12-2014-0124

Abernethy, M.A., \& Lillis, A.M. (1995). The Impact of Manufacturing Flexibility on Management Control System Design. Accounting, Organizations \& Society, 20(4), 241-258. https://doi.org/10.1016/0361-3682(94)E0014-L

Abu-Shanab, E., Abu-Shanab, R., \& Khairallah, M. (2015). Critical Success Factors for ERP Implementation: The Case of Jordan. The International Arab Journal of e-Technology, 4(1), 1-7.

Al Azmi, N., Al-Lozi, M., Al-Zu'bi, Z., Dahiyat, S., \& Masa'deh, R. (2012). Patients Attitudes toward Service Quality and its Impact on their Satisfaction in Physical Therapy in KSA Hospitals. European Journal of Social Sciences, 34(2), 300-314.

Alalwan, A., Rana, N., Algharabat, R., \& Tarhini, A. (2016). A Systematic Review of Extant Literature in Social Media in the Marketing Perspective, The 15th IFIP Conference on e-Business, e-Services and e-Society, Swansea, UK (13-15, Sep 2016) (pp.79-89). Springer International Publishing.

Al-Badi, A., Tarhini, A., \& Al-Kaaf, W. (2017). Financial Incentives for Adopting Cloud Computing in Higher Educational Institutions. Asian Social Science, 13(4), 162-174. https://doi.org/10.5539/ass.v13n4p162

Al-Badi, A., Tarhini, A., \& Al-Sawaei, S. (2017). Utilizing Social Media to Encourage Domestic Tourism in Oman. International Journal of Business and Management, 12(4), 84-94. https://doi.org/10.5539/ijbm.v12n4p84

Alenezi, H., Tarhini, A. Masa'deh, R. Alalwan, A., \& Al-Qirim, N. (2017). Factors Affecting e-Government Adoption in Kuwait: A Qualitative study. Electronic Journal of e-Government, 15(2), 84-102.

Alkalha, Z., Al-Zu'bi, Z., Al-Dmour, H., \& Alshurideh, M. (2012). Investigating the Effects of Human Resource Policies on Organizational Performance: An Empirical Study on Commercial Banks Operating in Jordan. European Journal of Economics, Finance and Administrative Sciences, 51, 44-64.

Almajali, D. A., Masa'deh, R., \& Tarhini, A. (2016). Antecedents of ERP Systems Implementation Success: A Study on Jordanian Healthcare Sector. Journal of Enterprise Information Management, 29(4), 549-565. https://doi.org/10.1108/JEIM-03-2015-0024 
Alrowwad, A., Obeidat, B.Y., \& Aqqad, N. (2017). The impact of transformational leadership on organizational performance via the mediating role of corporate social responsibility: A structural equation modeling approach. International Business Research, 10(1), 199-221. https://doi.org/10.5539/ibr.v10n1p199

Alshurideh, M., Masa'deh, R., \& Alkurdi, B. (2012). The Effect of Customer Satisfaction on Customer Retention in the Jordanian Mobile Market: An Empirical Investigation. European Journal of Economics, Finance and Administrative Sciences, 47, 69-78.

Altamony, H., Alshurideh, M., \& Obeidat, B. (2012). Information Systems for Competitive Advantage: Implementation of an Organizational Strategic Management Process. Proceedings of the 18th IBIMA Conference on Innovation and Sustainable Economic Competitive Advantage: From Regional Development to World Economic, Istanbul, Turkey, 9th-10th May.

Anderson, S. W., \& Young, S. M. (1999).The Impact of Contextual and Factors on the Evaluation of Activity-based Costing Systems. Accounting, Organizations and Society, 24, 525-559. https://doi.org/10.1016/S0361-3682(99)00018-5

Arnold, V., Lampe, J., Masselli, J., \& Sutton, S. (2000). An Analysis of the Market for Systems Reliability Assurance Services. Journal of Information Systems, 14, 65-82. https://doi.org/10.2308/jis.2000.14.s-1.65

Bledsoe, N. L., \& Ingram R. W. (1997).Customer Satisfaction through Performance Evaluation. Journal of Cost Management, Winter, 43-50.

Boritz, E., \& Hunton, J. (2002). Investigating the Impact of Auditor-Provided Systems Reliability Assurance on Potential Service Recipients. Journal of Information Systems, 16, 69-88. https://doi.org/10.2308/jis.2002.16.s-1.69

Branch, B., \& Gale, B. (2000).Linking Corporate Stock Price Performance to Strategy Formulation. The Journal of Business Strategy, 4, 40-50. https://doi.org/10.1108/eb039005

Bromwich, M., \& Bhimani, A. (1994). Management Accounting: Pathways to Progress. London: Chartered Institute of Management Accountants.

Choe, J.M. (2002). The Organizational Learning Effect of Management Accounting Information under Advanced Manufacturing Technology. European Journal of Information Systems, 11, 142-158. https://doi.org/10.1057/palgrave/ejis/3000424

Coe, M. (2005). Trust Services: A Better Way to Evaluate IT Controls. Journal of Accountancy, 199(3).

Committee of Sponsoring Organizations of the Treaway Commission (COSO). (1992). Internal Control-Integrated Framework. Coopers \& Lybrand, September, 1-4.

Dugdale, D. (1994). Theory and Practice: The Views of CIMA and Students. Management Accounting (UK), 56-59.

El-Masri, M., \& Tarhini, A. (2015). A Design Science Approach to Gamify Education: From Games to Platforms. Twenty-Third European Conference on Information Systems (ECIS), Münster, Germany. 26-29 May 2015.

El-Masri, M., Orozco, J., Tarhini, A., \& Tarhini, T. (2015). The Impact of IS-Business Alignment Practices on Organizational Choice of IS-Business Alignment Strategies. The 19th Pacific Asia Conference on Information Systems (PACIS 2015), Paper 215, Singapore, 6-9 July 2015.

Gu, F. (2005). Innovation, Future Earnings, and Market Efficiency. Journal of Accounting Auditing and Finance, 20(4), 385-418. https://doi.org/10.1177/0148558X0502000405

Gunasekarana, A., Williamsb, J., \& McGaughey, R. (2005). Performance Measurement and Costing System in New Enterprise. Technovation, 25, 523-533. https://doi.org/10.1016/S0166-4972(03)00176-7

Hajir, J., Obeidat, B., \& Al-dalahmeh, M. (2015). The Role of Knowledge Management Infrastructure in Enhancing Innovation at Mobile Telecommunication Companies in Jordan. European Journal of Social Sciences, 50(3), 313-330.

Hassouna, M., Elyas, T., \& Abou Trab, M. S. (2015). Customer Churn in Mobile Markets: A Comparison of Techniques. International Business Research, 8(6), 224-237. https://doi.org/10.5539/ibr.v8n6p224

Havelka, D., Sutton, S.G., \& Arnold, V. (1998). A Methodology for Developing Measurement Criteria for Assurance Services: An Application in Information Systems Assurance. Auditing: A Journal of Practice and Theory, 73-92. 
Hunton, J.E., Benford, T., Arnold, V., \& Sutton, S.G. (2000).The Impact of Electronic Commerce Assurance on Financial Analysts' Earnings Forecasts and Stock Price Estimates. Audit J Pract Theory, 18, 5-22.

Ibrahim, A.R., Zolait, A.H., \& Sundram, V.P. (2010). Supply Chain Management Practices and Firm Performance: An Empirical Study of the Electronics Industry in Malaysia. International Journal of Technology Diffusion, 1(3), 48-55. https://doi.org/10.4018/jtd.2010070103

Ibrahim, M. E. (1999). Recent Trends to Modernize Performance Evaluation Systems in Economic Enterprises. Administrative Research Review, 11(3), 91-99.

Isobe, T., Makino, S., \& Montgomery, D.B. (2008). Technological Capabilities and Firm Performance: The Case of Small Manufacturing Firms in Japan. Asia Pacific Journal, 25, 413-428. https://doi.org/10.1007/s10490-008-9098-z

Ittner, C. D., \& Larcker, D. F. (2003). Coming up Short on Nonfinancial Performance Measurement. Harvard business review, 81(11), 88-95.

Kanaan, R., \& Gharaibeh, A. (2013). The Impact of Knowledge Sharing Enablers on Knowledge Sharing Capability: An Empirical Study on Jordanian Telecommunication Firms. European Scientific Journal, 9(22), 237-258.

Kaplan, R. S., \& Norton, D. P. (1992, January-February). The Balanced Scorecard-Measures that Drive Performance. Harvard Business Review, 78, 71-79.

Kaplan, R. S., \& Norton, D. P. (2001a). The Strategy focused Organisation - How Balanced Scorecard Organisations Thrive in the New Business Environment. Harvard Business School Press.

Kaplan, R. S., \& Norton, D. P. (2001b). Transforming the Balanced Scorecard from Performance Measurement to Strategic Management, Part 1. American Accounting Association, 15(1), 87-104.

Kaplan, R. S., \& Norton, D. P. (2001c). Transforming the Balanced Scorecard from Performance Measurement to Strategic Management, Part 2. American Accounting Association, 15(2), 147-160.

Kelly, K. O. (2007). Feedback and Incentives on Nonfinancial Value Drivers: Effects on Managerial Decision Making. Contemporary Accounting Research, 24(2), 523-556. https://doi.org/10.1506/Q5X8-5912-W613-0UTL

Khazanchi, D., \& Sutton, S.G. (2001). Assurance Services for Business-to-Business Electronic Commerce: A Framework and Implications. Journal of the Association for Information Systems, 1, 1-53.

Lala, V., Arnold, V., Sutton, S. G., \& Guan, L. (2002). The Impact of Relative Information Quality of Ecommerce Assurance Seals on Internet Purchasing Behavior. International Journal of Accounting Information Systems, 3(4), 237-253. https://doi.org/10.1016/S1467-0895(02)00069-6

Masa'deh, R. (2013). The Impact of Information Technology Infrastructure Flexibility on Firm Performance: An Empirical Study of Jordanian Public Shareholding Firms. Jordan Journal of Business Administration, 204-224. https://doi.org/10.12816/0002054

Masa'deh, R., Gharaibeh, A., Maqableh, M., \& Karajeh, H. (2013). An Empirical Study of Antecedents and Outcomes of Knowledge Sharing Capability in Jordanian Telecommunication Firms: A Structural Equation Modeling Approach. Life Science Journal, 10(4), 2284-2296.

Masa'deh, R., Obeidat, B.Y., \& Tarhini, A. (2016). A Jordanian Empirical Study of the Associations Among Transformational Leadership, Transactional Leadership, Knowledge Sharing, Job Performance, and Firm Performance: A Structural Equation Modelling Approach. Journal of Management Development, 35(5), 681-705. https://doi.org/10.1108/JMD-09-2015-0134

Masa'deh, R., Tayeh, M., Al-Jarrah, I., \& Tarhini, A. (2015). Accounting vs. Market-based Measures of Firm Performance Related to Information Technology Investments. International Review of Social Sciences and Humanities, 9(1), 129-145.

Masa'deh, R. (2012). The Impact of Management Information Systems (MIS) on Quality Assurance (QA): A Case Study in Jordan. International Journal of Information, Business, and Management, 93-110.

Masa'deh, R., \& Shannak, R. (2012). Intermediary Effects of Knowledge Management Strategy and Learning Orientation on Strategic Alignment and Firm Performance. Research Journal of International Studies, 112-128.

Masa'deh, R., Gharaibeh, A., Tarhini, A., \& Obeidat, O. (2015). Knowledge Sharing Capability: A Literature Review. In Fourth Scientific \& Research Conference on New Trends in Business, Management and Social Sciences, Istanbul, Turkey, 19-20 September 2015 (pp. 1-16). https://doi.org/10.2139/ssrn.2696924 
Masa'deh, R., Maqableh, M., \& Karajeh, H. (2014). A Theoretical Perspective on the Relationship between Leadership Development, Knowledge Management Capability, and Firm Performance. Asian Social Science, 10(6), 128.

Masa'deh, R., Shannak, R., Maqableh, M., \& Tarhini, A. (2017). The Impact of Knowledge Management on Job Performance in Higher Education: The Case of the University of Jordan. Journal of Enterprise Information Management, 30(2), 244-262. https://doi.org/10.1108/JEIM-09-2015-0087

Meharia, P. (2012). Assurance on the Reliability of Mobile Payment System and its Effects on its' Use: An Empirical Examination. Accounting and Management Information Systems, 11(1), 97-111.

Menon, K., \& Williams, J. D. (1994).The Use of Audit Committees for Monitoring. Journal of Accounting and Public Policy, 13(2), 121-139. https://doi.org/10.1016/0278-4254(94)90016-7

Miller, J.A. (1992). Designing and Implementing a New Cost Management System. Journal of Cost Management, Winter, 41-53.

Nelson, R. R., Todd, P. A., \& Wixom, B. H. (2005). Antecedents of Information and System Quality: An Empirical Examination within the Context of Data Warehousing. Journal of Management Information Systems, 21(4), 199-235. https://doi.org/10.1080/07421222.2005.11045823

Obeidat, B., El-Rimawi, S., Maqableh, M., \& Al-Jarrah, I. (2013). Evaluating the Profitability of the Islamic Banks in Jordan. European Journal of Economics, Finance and Administrative Sciences, 56, 27-36.

Obeidat, B., Sweis, R., Zyod, D., \& Alshurideh, M. (2012). The Effect of Perceived Service Quality on Customer Loyalty in Internet Service Providers in Jordan. Journal of Management Research, 4(4), 224-242. https://doi.org/10.5296/jmr.v4i4.2130

Obeidat, B., Tarhini, A., Masa'deh, R., \& Aqqad, N. (2017). The Impact of Intellectual Capital on Innovation via the Mediating Role of Knowledge Management: A Structural Equation Modeling Approach. International Journal of Knowledge Management Studies. https://doi.org/10.1504/IJKMS.2017.10007246

Obeidat, B.Y., Al-Hadidi, A., Tarhini, A., \& Masa'deh, R. (2017). Factors Affecting Strategy Implementation: A Case Study of Pharmaceutical Companies in the Middle East. Review of International Business and Strategy, 27(3), 22-35. https://doi.org/10.1108/RIBS-10-2016-0065

Obeidat, B.Y., Al-Sarayrah, S., Al-Dmour, R. H., Al-Salti, Z., \& Sweis, R. (2016). Cultural Influence on Strategic Human Resource Management Practices: A Jordanian case study. International Business Research, 9(10), 94-114. https://doi.org/10.5539/ibr.v9n10p94

Otley, D. (2001). Extending the Boundaries of Management Accounting Research: Developing Systems for Performance Management. British Accounting Review, 33(3), 243-261. https://doi.org/10.1006/bare.2001.0168

Perego, P. (2009, December). Causes and Consequences of Choosing Different Assurance Providers: An International Study of Sustainability Reporting. International Journal of Management, 26(3), 412-425.

Pierce, B., \& O'Dea, T. (1998). Management Accounting Practices in Ireland-The Preparers' Perspective. DUCBS Research Papers No. 34, Dublin City University Business School.

Ross, S.A., Westerfield, R.W., \& Jaffe, J. (1996). Corporate Finance. Boston, MA, Ediţia.

Shannak, R., Obeidat, B., \& Almajali, D. (2010). Information Technology Investments: A Literature Review. Proceedings of the 14th IBIMA Conference on Global Business Transformation through Innovation and Knowledge Management: An Academic Perspective, Istanbul-Turkey, 23rd-24th June, pp.1356-1368.

Siponen M. T., \&Oinas-Kukkonen, H. (2007). A Review of Information Security Issues and Respective Research Contributions. ACM SIGMIS Database, 38(1), 60-80. https://doi.org/10.1145/1216218.1216224

Sousa, S., Elaine, M., Aspinwal, A., \& Guimaraes, R. (2006). Performance Measures in English Small Medium Enterprises: $\quad$ Survey Result. Benchmarking: An International Journal, 13(1), 120-134. https://doi.org/10.1108/14635770610644628

Strong, D. M., Lee, Y. W., \& Wang, R. Y. (1997). Data Quality in Context. Communications of the ACM, 40(5), 103-110. https://doi.org/10.1145/253769.253804

Tarhini, A., Arachchilage, N. A. G., Masa'deh, R., \& Abbasi, M.S. (2015). A Critical Review of Theories and Models of Technology Adoption and Acceptance in Information System Research. International Journal of Technology Diffusion (IJTD), 6(4), 58-77. https://doi.org/10.4018/IJTD.2015100104 
Tarhini, A., El-Masri, M., Ali, M., \& Serrano, A. (2016). Extending the UTAUT model to understand the customers' acceptance and use of internet banking in Lebanon: A structural equation modeling approach. Information Technology and People, 29(4), 830-849. https://doi.org/10.1108/ITP-02-2014-0034

Tarhini, A., Masa'deh, R., Al-Badi, A., Almajali, M., \& Alrabayaah, SH. (2017). Factors Influencing Employees' Intention to Use Cloud Computing. Journal of Management and Strategy, 8(2), 47. https://doi.org/10.5430/jms.v8n2p47

Tuanmat, Z., \& Smith, M. (2011). The Effect of Changes in Competition, Technology and Strategy on Organizational Performance in Small and Medium Manufacturing Companies. Asian Review of Accounting, 19(3), 208-220. https://doi.org/10.1108/13217341111185137

Verschoor, C. C. (1999). Corporate Performance is Closely Linked to strong ethical commitment. Business and Society Review, 104(4), 407-415. https://doi.org/10.1111/0045-3609.00074

Vratskikh, I., Al-Lozi, M., \& Maqableh, M. (2016). The Impact of Emotional Intelligence on Job Performance via the Mediating Role of Job Satisfaction. International Journal of Business and Management, 69-91. https://doi.org/10.5539/ijbm.v11n2p69 